\title{
Uninterrupted prayer - A spiritual challenge
}

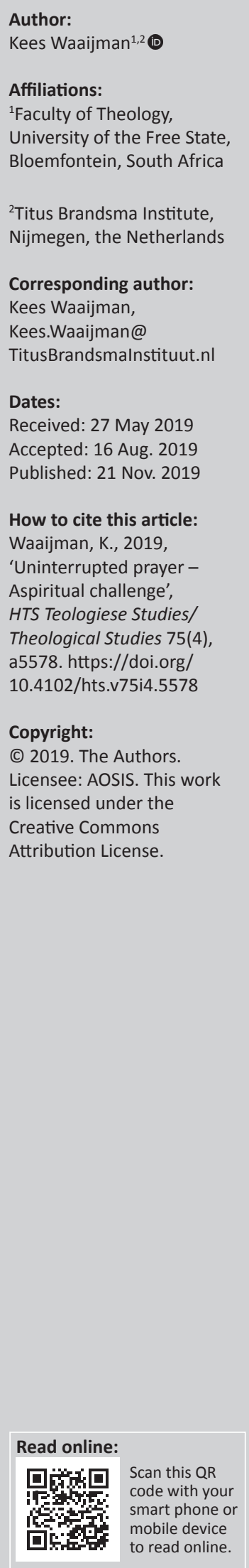

This contribution probes the question how the biblical instruction to pray continuously was understood in the history of Christian spirituality. It investigates two main traditions of interpretation. The first tradition interprets the instruction from a material-temporal perspective. Prayer should be, in the literal sense of the word, everlasting, never ending and perpetual. The second tradition focuses more on the relationship with God, its permanent character, and its lasting and enduring quality. It has to do with the question how a sustainable growth can be improved. It is a spiritual challenge, requiring an in-depth understanding and conversation, to consider and reflect on the difficult and complex interaction between these two approaches.

Keywords: prayer; 1 Thessalonians 5:17-18; spirituality; spiritual practices; uninterrupted prayer.

\section{Introduction}

'Prayer without ceasing' is a central theme in the history of Christian spirituality. ${ }^{1}$ The New Testament contains the commandment to pray uninterruptedly in 36 places. The best-known quotations are from Luke and Paul. Luke (18:1) reports how Jesus told his disciples 'a parable about the need to pray continually and never lose heart'. ${ }^{2}$ Paul writes in his letter to the Thessalonians: 'Pray constantly, and for all things give thanks' (1 Th 5:17-18). The Greek original reads, à $\delta 1 \alpha \lambda \varepsilon i ́ \tau \tau \omega \varsigma$

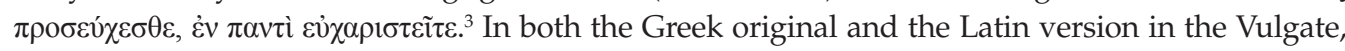
there is this connotation: do not disrupt your prayer by putting something (time or space or another obstacle) in between. The Greek adverb $\dot{\alpha} \delta 1 \alpha \lambda \varepsilon i ́ \pi \tau \omega \varsigma$ can be translated in four ways as continuously, uninterruptedly, constantly and without ceasing. These nuances are important in the reception of the commandment of prayer 'without ceasing' in the history of Christian spirituality.

This contribution probes the question how this biblical instruction to pray continuously was understood in the history of Christian spirituality. It investigates two main traditions of interpretation. The first tradition interprets the instruction from a material-temporal perspective. Prayer should be, in the literal sense of the word, everlasting, never ending and perpetual. The second tradition approaches it from a processual-dialogical interpretation, focusing more on the relationship with God, its permanent character, and its lasting and enduring quality. It has to do with the question how sustainable growth can be attained. It is a spiritual challenge to consider and reflect on the difficult and complex interaction between these two approaches. It requires an in-depth understanding and conversation.

\section{The material-temporal interpretation}

Interpretations that emphasise the material-temporal continuity of prayer sought to determine the forms of visible and tangible temporal permanence. Such a material continuity is not easy to spell out, with the result that communities developed different solutions to address this temporal problem. This can be illustrated by the following examples.

Some monks in the desert tried to pray the whole psalter with its 100 and 50 psalms aloud every day as their attempt to fulfil the commandment of the Lord 'to pray always and not to lose heart'. They did not sleep to pray the whole day and night without any interruption. They were therefore called the akoimetoi, the sleepless monks (Bacht 1957:244). Their understanding of the Lord's commandment was to fill their time with prayers.

1.For an exegetical and historical overview, see Gülden (1980:327-336) and Kerkhoff (1954)

2.The Vulgate translates: 'Semper orare et non deficere'.

3.The Vulgate translates: 'Sine intermissione orate'. 
Other monks founded monasteries that focused specifically on permanent prayer. They divided themselves in two or more groups and prayed the psalms and other prayers in successive sections throughout the day and night (Gülden 1980:330-331). For them, the very reason of these monasteries was also to incarnate the commandment of the Lord to pray uninterruptedly. This approach represents a kind of assembly line for prayer. The practice of everlasting adoration is modelled on this same principle: members of a community take each other's place and together they realise the uninterrupted adoration.

A more interiorised form of continuous prayer, but seeking to implement the same idea of perpetuality, is the Jesus prayer. This form of prayer is built on continuous repetition, ending up in something like automatic speech, as the Jewish mystic Joseph Karo explained it, or something like diqr in the Islamic tradition. The repetition is so deeply interiorised in the soul of the prayer that the prayer repeats itself. Even in sleep, such a repetitive prayer works as a perpetuum mobile. This uninterrupted prayer gives deep feelings of satisfaction. Sometimes, quick prayers have the same effect. Work is interrupted regularly when the praying person lifts the eyes to heaven and offers up a quick prayer. Alternatively, people pray the rosary several times a day to feel certain permanence in their prayer. This approach has the same outcome: it represents continuity of behaviour that creates continuity in time.

A rather modern form of continuous prayer is the idea of a world-wide church praying the liturgy of the hours. For this reason, Vatican II connects the commandment of everlasting prayer with the liturgy of hours. The idea is that the divine office is practised all over the world in successive waves. This means that there are always and everywhere people praying the official prayer of the church. By doing so, the church fulfils the commandment of the Lord to pray without ceasing. Here, the category of continuous space has taken over the category of continuous time. It represents a kind of relay race in prayer.

In all these examples, people try to fulfil the commandment of the Lord by translating the category of uninterrupted time into concrete categories of physical repetition, cooperation, behaviour or space. This explains why it can be described as a material-temporal solution.

\section{The processual-dialogical interpretation}

In the processual-dialogical interpretation of the biblical instruction, the category of continuous time is translated into the category of a dialogical process to indicate a process of continuous transformation. This interpretation can also be illustrated in terms of different examples.

Clement of Alexandria, for instance, interpreted everlasting prayer in a broader sense as having to do with our whole life, with all we are and all we do in our daily lives. Someone prays continuously, when 'he transforms his whole life into prayer'. ${ }^{4}$ Origenes followed his teacher Clement in his broadening the horizon of prayer, explicitly including all our activities in the concept of uninterrupted prayer. He noted, 'Praying without interruption is performed by a person, who connects the necessary activities and the practices of the virtues with a prayerful life' ${ }^{5}$ Origenes accordingly states that 'the whole life of a pious person is one great composition of prayer, in which what we normally name as "prayer" is just a part'. ${ }^{6}$ He concludes that this is the only way 'we are able to fulfill the commandment of prayer without interruption'.?

Famous is the mystical interpretation of abbot Isaac, a desert monk, who is regarded as the expert in prayer. For him, the uninterruptedness of prayer is embedded in the divinehuman relationship. Every prayer can become a mystical encounter with God, and precisely, this is its uninterruptedness. His interpretation is developed as follows. ${ }^{8}$ The point of departure is, 'The mental state of the praying person during prayer is determined by what precedes his prayer'. ${ }^{9}$ All the things that obsess him before praying play a role in his prayer, including what he did, what he said, what he felt, what he memorised, what he expected and what he feared. 'Let us therefore drive away, before our prayer, all these things which we do not like as hindrances in our prayer ${ }^{\prime}{ }^{10}$ Isaac has in mind matters like over-anxiousness, exaggerating efforts and too much property. ${ }^{11}$

All these hindrances should be left behind when one enters into praying. This is the only way to pray 'without interruption' (sine intermissione) because there will be nothing that disturbs the immediate relationship between God and the heart.

'Without interruption' is thus understood by Isaac as a processual-dialogical quality, not as a temporal-material issue.

Abbot Isaac compares this uninterrupted prayer to a small feather that is moved by the slightest breeze which lifts it in the air. ${ }^{12}$ Isaac explains: 'On the lightest breeze of a spiritual meditation, the spirit is lifted up, to be transferred into heaven and the invisible'. ${ }^{13}$ How does this soul come out of this uninterrupted prayer? As light as a little feather. Moved by God, the soul goes out to all creatures, and all the 4.Clemens van Alexandrië, Stromata 7,35,1-3; cf. 7,73,1.

5.Origenes, De oratione 12,2.

6.Origenes, De oratione 12,2.

7.Origenes, De oratione 12,2.

8.Johannes Cassianus, Collationes 9,1.

9.Johannes Cassianus, Collationes 9,3; see also 10,14.

10.Johannes Cassianus, Collationes 9,3

11.Johannes Cassianus, Collationes 9,5

12.Johannes Cassianus, Collationes 9,3

13.Johannes Cassianus, Collationes 9,4. 
enterprises of the soul will be the purest and most perfect prayer. ${ }^{14}$ Thus, in the view of abbot Isaac, uninterrupted prayer is qualified by the processual transition from being hindered by one's own occupations, into a state of being not hindered at all, sine intermissione. It is basically a process of transformation: going into prayer, losing one's preoccupations, being in prayer in immediate contact with God, going out of prayer and moved by God.

Augustine, looking for a strong fundament for a prayerful life, considers the human desire as the deepest layer. In his view, a spiritual life tries to discover the longing for God in all our needs and desires. His presupposition is that, on its most fundamental level, human desire is longing for God. Spiritual life is to discern step by step, in all our needs and desires, the need for God. If someone comes into contact with this existential outreach to God, that person is in prayer. Hence, his often-quoted statement: 'Desire is always praying'.${ }^{15}$ Augustin translates the temporal continuity into the permanence of our longing, which is longing for God.

The Carmelite tradition tries to understand the commandment of the uninterrupted prayer in the light of the motto of the prophet Elijah: 'The Lord lives, in whose presence I stay' ${ }^{16}$ Staying before the countenance of God is a fundamental exercise in Carmelite spirituality, and the basic condition for the mystical transformation. Living in the presence of God is not an isolated activity, but rather a way of life, performed in every situation and in every activity: the awareness of being seen and loved by God. Uninterrupted prayer is living in this presence of God (Brandsma 1936:11-13). Daily prayers are, as daily work, activities steeped in the presence of God. Ruusbroec expresses the same idea in his Vanden Blinckenden Steen, when he notes that we should go out from ourselves in ardent prayer and in uninterrupted adherence to God.

In the Ignatian tradition, the concept of uninterrupted prayer is translated into contemplation in all our activities (contemplativus in actione). Ignatius' adage or basic idea is: 'Finding God in all things' (Wulf 1960:549-550). All activities, done for the greater honour of God, are as such prayer and at the end a contemplative eye looking for God in every activity.

These processual-dialogical approaches try to discover an indepth spiritual layer in our life itself, in our daily life, our immediate connectedness with God, our longing for God, our being in his presence and in our involvement in his creative love. This deeper level is understood as being continuously in prayer.

\section{A difficult conversation}

Is it possible to connect the two lines described thus far? Are they connected intrinsically? Or do they belong to separate worlds? Before proposing an answer, an example of a difficult

14.Johannes Cassianus, Collationes 9,6 .

15.Augustinus, Epistola ad Probam, Epistola 130.

16.See, for example, 1 Kings 17:1, 18:15; 2 Kings 3:14, 5:16. conversation between two highly spiritual persons is useful. This conversation took place in the 4th century between abbot Epiphanius, the founder of a monastery in Gaza, his birthplace. As abbot of this desert community, Epiphanius trained his monks in the practice of uninterrupted prayer during a period of 30 years. He instructed them in praying the psalms as a contemplative exercise practised in those days by many desert monks, continuously and permanently, sometimes by repeating one sentence only, namely 'Be pleased, O God, to rescue me. O Lord, make haste to help me!' (Ps 70:1). ${ }^{17}$ The basic exercise was reading the psalms as lectio divina: by saying, meditating, praying and contemplating a peace of a psalm, slowly, attentively, in a spiritual rhythm of praying, ending up in contemplation.

Epiphanius was asked to become the bishop of Cyprus. After his departure, his successor decided to change the order of prayer. It was no longer about praying the psalms continuously in the mode of lectio divina, but, in a new way, about praying the hours at fixed times, on the so-called canonical hours, that is seven prayer times daily and a long prayer session at night. The new abbot, very enthusiastic about this renewal of the divine office, wrote to Epiphanius, the former abbot, but then the new bishop of Cyprus: 'With the help of your prayer, we nowadays perform our liturgy of the hours on the canonically established hours'. Epiphanius did not appreciate the transition from the monastic way of praying the psalms to the canonically established hours. 'It is clear', Ponticus (1987) wrote:

[T] hat you neglect the other hours of the day, because on these other hours you are not occupied by prayer. The true monk should pray uninterruptedly and the saying of the psalms should be in his heart. (p. 78)

Epiphanius could not find common ground between the two different forms of the divine office: he separated the relativity of temporal-material schemes, on the one hand, from the spiritual transformation aimed at by the monastic praying of the psalms or the canonical hours. He focused on the level of time: saying the psalms in the monastic way covers all hours of the day, but praying on the canonical hours covers only 8 $\mathrm{h}$ a day. What to do with the other hours?

This miscommunication is typical of many other times. Time and again, people are obsessed by continuous prayer in the material-temporal sense. They do not recognise the deeper objective of divine human transformation. On the other hand, people obsessed by mystical processes do not understand the anthropological need for temporal-spatial incarnation in our bodily structures. The question thus remains how to facilitate the difficult conversation between a material-temporal scope and a processual-dialogical perspective.

\section{Two principles}

In my opinion, there are two principles that may be helpful to bridge the gap between too much materialism and too much 17.For a discussion, see Waaijman (2014:33-34). 
spiritualisation in fulfilling the instruction to pray without ceasing. The first principle reflects positively on the materialtemporal infrastructure of prayer. To restrict the exaggerating tendency of quantitative expansion of prayer, the category of pars pro toto is needed. To bring down to earth the mystical tendency of spiritualisation, the dynamic of ongoing transformation should be considered.

The basic principle of pars pro toto is first of all about a literary figure of speech: a part represents the whole. For instance, 'counting noses' refers to 'counting persons'. 'A flower' refers to 'a bunch of flowers'. Pars pro toto is, furthermore, also a liturgical principle. For the Eucharist, a small piece of bread represents a whole meal. A small part of Holy Scripture represents the whole of God's word. A single passage evokes the whole of a book. For baptism, some water is sufficient. One does not need a whole river. For the liturgy of hours, the same principle is applicable: the prayer should not be extended over endless quantity of time to represent day and night.

Pars pro toto is also a spiritual principle of trying to live a part as the whole. Jesus thus teaches in the Sermon of the Mount that the whole body will be filled with light if the vision is clear (Mt 6:22). This insight appeals to our trust and questions our inclination to purify ourselves endlessly, till, literally, all is completely purged. This propensity is to be seen in Peter's conversation with Jesus. Initially, Peter refused resolutely, 'You will never wash my feet'. But then he changed his mind completely, 'Well then, Lord, not only my feet, but my hands and my head as well'. But Jesus said: 'If your feet are washed, your whole body is clean' (Jn 13:9-10). The washing of a part is the cleansing of the whole. This is a spiritual exercise, a training in trusting and letting go. Let go the tendency to purify yourself completely in the material sense.

Other examples include the saying that a little bit of yeast is enough to let leaven all the flour (Mt 13:33), that the little tongue is enough to keep the whole person in check, that a little bit is enough to guide the whole horse, that ships are guided by a very small rudder and that a forest is set ablaze by a small fire (Ja 3:1-12). All these images demonstrate the same tenor: a part represents the whole. The spiritual training is trying to participate in the whole by performing a part.

The other principle is about insight and training in mystical transformation. Mystical transformation leads us from our temporal-spatial self-centeredness into the free space of God's love. Essentially, this process is seen from our human perspective, a process of letting go, of giving over the initiative to God. This is about a training in trust and at the same time, basically, a training in prayer: 'Take over, my Lord, what I am doing'.

'Let me be an instrument in your hand'. This transformation is not dependent on quantity but on quality: concentration and letting go. This is exactly what abbot Isaac tried to teach us: if you go to prayer, let go all your self-centred concerns, just for the time you are praying, try to forget your self-centred attitude. Give up your initiative, just for a moment, and God will take over.

Both principles are necessary. They bring one another in balance: The principle of pars pro toto teaches us to respect our bodily conditions and the need for incarnation. Without any temporal-spatial form of performance, prayer will not grow in our real daily life. The other principle of mystical surrender is the soul of every prayer and makes it free from neurotic obsessions. Together they may help us to keep our bodily spiritual existence in balance: two hands lifted up, like in prayer, working together and helping one another.

Finally, there is much to be learned from Simone Weil, who remarked that one should pray just one Our Father in the morning, with complete attention. One Our Father, no more, and it will permeate one's whole day. It will transform one's soul in love.

\section{Acknowledgements Competing interests}

The author has declared that no competing interests exist.

\section{Author(s) contributions}

K.W. is the sole author of this research article.

\section{Ethical consideration}

This article followed all ethical standards for a research without direct contact with human or animal subjects.

\section{Funding information}

Financial support was received from the UFS for the publication of this article.

\section{Data availability statement}

Data sharing is not applicable to this article as no new data were created or analysed in this study.

\section{Disclaimer}

The views and opinions expressed in this article are those of the author and do not necessarily reflect the official policy or position of any affiliated agency of the author.

\section{References}

Bacht, H., 1957, 'Akoimeten', Lexikon für Theologie und Kirche 1, 244.

Brandsma, T., 1936, Carmelite Mysticism. Historical sketches, The Carmelite Press, Darien.

Gülden, J., 1980, 'Vom unablässigen Beten', in J. Plöger (ed.), Gott feiern, Theologische Anregung und geistliche Vertiefung zur Feier vom Messe und Stundengebet, pp. 327-336, Herder, Freiburg-Basel-Wien.

Kerkhoff, R., 1954, Das unablässige Gebet. Beiträge zur Lehre vom immerwährenden Beten im Neuen Testament, Zink, München.

Ponticus, E., 1987, Gerontikon, Translated and introduced by Christofoor Wagenaar, Abdij Bethlehem, Bonheiden.

Waaijman, K., 2014, Psalmvieringen, pp. 33-34, Titus Brandsma Memorial, Nijmegen. Wulf, F., 1960, 'Gebet', Lexikon für Theologie und Kirche 4, 549-550. 